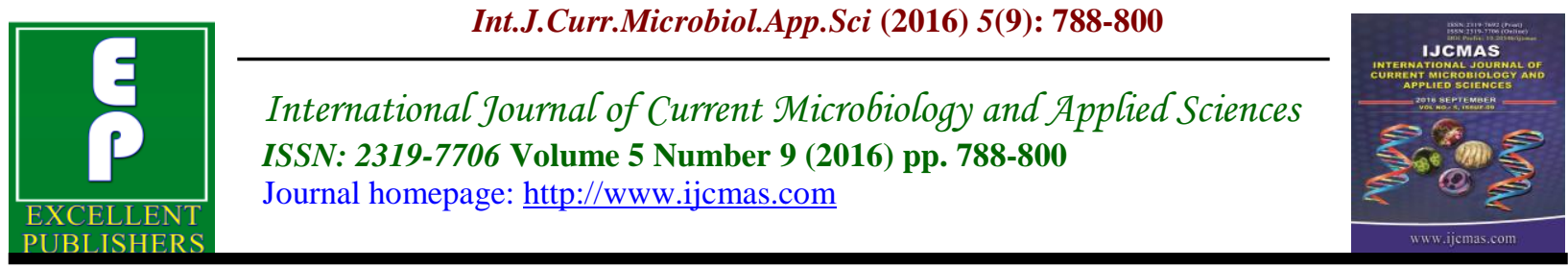

Original Research Article

http://dx.doi.org/10.20546/ijcmas.2016.509.090

\title{
Safe Approach to the Biological Control of the Fusarium oxysporum by Soil Isolates of Bacillus species from Gaza Strip
}

\author{
Abboud Y. Elkichaoui* \\ Biotechnology Department, Faculty of Science, Islamic University of Gaza, Gaza strip, Palestine \\ *Corresponding author
}

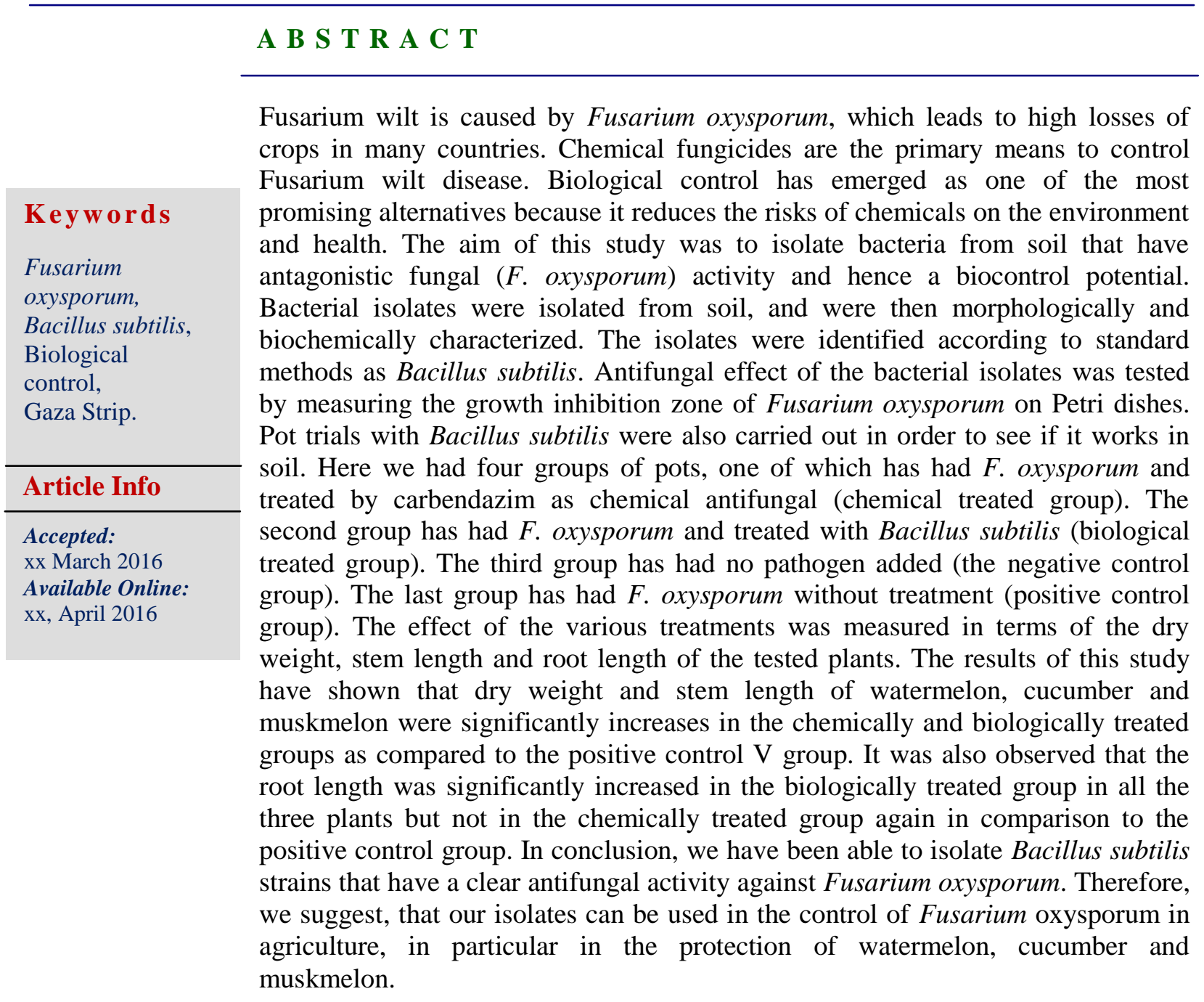

\section{Introduction}

Fungal plant diseases are one of the major concerns to agriculture worldwide. It has been estimated that total losses as a consequence of plant diseases reach $25 \%$ of 
the yield in western countries and almost $50 \%$ in the developing countries. Of these diseases, one third is due to fungal infections (Bowyer, 1999).

Fusarium species are among the most important plant pathogens in the world. Fusarium oxysporum is responsible for wilt and cortical rot diseases of more than 100 economically important plants (Swift et al., 2002). Potential means of pathogen control and disease management are: regulation of production and transfer of propagation material, seed disinfestation, suppressive growing media, sanitation of the greenhouse by heating or chemicals, crop rotation, soil and substrate disinfestation using methyl bromide or solarization, biocontrol agents, and fungicides (Gamliel and Yarden, 1998).

So there is a pressing need to control fungal diseases that reduce the crop yield so as to ensure a steady and constant food supply to ever increasing world population. Conventional practice to overcome this problem has been the use of chemical fungicides, which have adverse environmental effects causing health hazards to humans and other non-target organisms, including beneficial life forms (Schickler \& Chet, 1997).

Carbendazim is a fungicide used to control a broad range of fungal diseases on arable crops, fruits, and vegetables in Gaza strip. It could be harmful to human health and the environment. Carbendazim works by inhibiting the development of fungi probably by interfering with spindle formation at mitotic cell division.

The wide use of synthetic chemicals has caused the development of resistant pathogenic populations (Biles and Martyn, 1989) The spiraling up cost of fungicides, pollution to soil, water and air due to continuous use of fungicides and development of resistant strains of pathogen to these chemicals are therefore now forcing scientists to look for biological methods, which are eco-friendly safe and more specific to pathogens (Saravanan and Valluvaparidasan, 2001).

Biological control is a non-chemical measure that has been reported in several cases to be as effective as chemical control (Guetsky et al., 2002). Biological control involves the use of beneficial microorganisms, such as specialized fungi and bacteria, to attack and control pathogens offers an environmentally friendly approach to the management of plant disease and can be incorporated into cultural and physical controls and limited chemical usage for an effective integrated pest management (IPM) system. Biological control can be a major component in the development of more sustainable agriculture system.

IPM strategy, the established view of biological control is that, even though it is safer than chemical control. It is less efficient and less reliable. To be realistic, we should not expect a very broad range of pest or disease control from biological agents, or that they control major pests or pest complexes in major crops in a wide range of environments (Powell, 1993).

The general mechanism of biological control can be divided into direct and indirect effects of the bio control agent (BCA) on the plant pathogen. Direct effects include competition for nutrients or space, production of antibiotic and lytic enzymes, inactivation of the pathogen's enzymes and parasitism. Indirect effects include all those aspects that produce morphological and biochemical changes in the host plant, such as tolerance to stress through enhanced root and plant development, solubilization or 
sequestration of inorganic nutrients, and induced resistance (Viterbo et al., 2002).

When testing bacterial and fungal isolates from the environment for biocontrol activities, between 1 and $10 \%$ show at least some capacity to inhibit the growth of pathogens in vitro. However, fewer isolates can suppress plant diseases under diverse growing conditions and fewer still have broad-spectrum activity against multiple pathogenic taxa. Nonetheless, intensive screens have yielded numerous candidate organisms for commercial development. Some of the microbial taxa that have been successfully commercialized and are currently marketed as Environmental Protection Agency EPA-registered bio pesticides include bacteria belonging to the genera Agrobacterium, Bacillus, Pseudomonas, and Streptomyces (United States Environmental Protection Agency).

Screening is a critical step in the development of bio control agents. The success of all subsequent stages depends on the ability of a screening procedure to identify an appropriate candidate. Many useful bacterial bio control agents have been found by observing zones of inhibition in Petri plates (Larkin and Fravel, 1998).

Fusarium wilt disease is caused by pathogenic forms of the soil - inhabiting fungus Fusarium oxysporum. Fusarium oxysporum is a major disease problem on many crops. Currently, control of this pathogen is generally by chemical control (fungicides), which create potential length and environmental effects. Thus, alternative control measures are needed. This research explores the potential of biological control for the management of this disease. In this study Fusarium oxysporum strains were collected from infected plants in the field. As a biological agent Bacillus spp. was collected from a fusarium wilt - suppressive soil was tested for their efficacy in controlling fusarium wilt.

This research explores the potential of biological control for the management of this disease. In this study Fusarium, oxysporum strains were collected from infected plants in the field. As a biological agent Bacillus spp. was collected from a fusarium wilt - suppressive soil was tested for their efficacy in controlling fusarium wilt.

\section{Materials and Methods}

\section{Isolation of Fusarium oxysporum}

Tissue selected for isolation should be typical of the diseased material. Ideally, freshly infected tissue or tissue at the advancing edge of a necrotic area should be selected (Burgess et al., 1988).

Necrotic tissues of plants were washed and cut into small pieces $(2 \mathrm{~mm})$. Sections of necrotic tissues were surface disinfested in 1 $\% \mathrm{NaClO}$ for $2 \mathrm{~min}$, rinsed in distilled water, and damp-dried on absorbent paper towels before being plated on the media (Farias, 1987). This procedure will reduce the chance of bacterial contamination. Removal of cortex will facilitate isolation of Fusarium oxysporum from vascular tissue (Burgess et al., 1988).

Then placed on Komada's Fusariumselective medium (Komada, 1975), and acidified potato dextrose agar (APDA). Many saprophytic fungi and bacteria also can grow on the medium and interfere with the recovery of the Fusarium present. If PDA is used for the recovery of fungi from plant material, then the concentration of potato and dextrose should be reduced by $50-75 \%$, and broad-spectrum antibiotics included inhibiting bacterial growth (Burgess et al., 1988). 
Plates were incubated at room temperature $\left(25-28^{\circ} \mathrm{C}\right)$. Fungi developing from the plated seedling segments were transferred to APDA and APDA-WA (water agar) to be identified. Fungal colonies were identified by microscopic observation of conidium and micro conidiophore morphology, along with the cultural characteristics on APDA, such as pigmentation and colony morphology (Burgess et al., 1988). The APDA-WA technique (Booth, 1971) was used for conidium, conidiophore morphology, and chlamydospore production by placing a small APDA plug (about $1 \mathrm{~cm} 2$ ) with the fungus on a $2 \% \mathrm{WA}$ plate. A glass cover slip was placed on the WA to facilitate microscopic observations. Fungal colonies were subcultured on PDA slants. Maintenance of cultures was done by transferring active cultures on PDA slants twice a year. After suitable growth and sporulation, the slants were kept at $4-5^{\circ} \mathrm{C}$.

\section{Isolation of Bacillus spp. from Soil}

Different soil samples were taken from Beit Hanoun and Biet Lahia. The grassland soil used in all experiments was collected from the $0-15 \mathrm{~cm}$ layer. Each gram of sample was suspended in $99 \mathrm{ml}$ of sterile distilled water and shaken vigorously for $2 \mathrm{~min}$ by vortex mixer. The samples were heated at $60^{\circ} \mathrm{C}$ for $60 \mathrm{~min}$ in a water bath. Then the soil suspensions were serially diluted in sterile distilled water, and the dilutions from 10-1 to 10-6 were plated on nutrient agar medium. The plates were incubated at 28 $37^{\circ} \mathrm{C}$ for $24-48$ hour $(93+94)$. Antagonistic isolates of bacteria were identified by biochemical (according to PIB win software).

\section{In vitro Inhibition of Fusarium oxysporum by Isolated Soil Bacteria}

Soil bacteria isolate were tested for their ability to inhibit Fusarium oxysporum in vitro, on agar plates as described by Weller and Cook (Weller and Cook, 1986) and Wong and Baker (Wong and Baker, 1984). The pathogenic Fusarium oxysporum was transferred to regular Petri dishes containing fresh PDA to produce fungal mycelium plugs. Each bacterial isolate was streaked at opposite ends of agar plates near the edge and incubated at $27 \pm 1^{\circ} \mathrm{C}$ for $48 \mathrm{~h}$. An agar plug (5 $\mathrm{mm}$ in diameter) containing fungal mycelium, taken from the radiating edge of a culture grown on PDA was placed in the center of each plate. Plates were incubated for about five days more or until the leading edge of the fungus reached the edge of the plate. The size of the zone of inhibition of fungal growth around each bacterial species was used as a measure of the ability of those bacteria to inhibit Fusarium oxysporum and was scored as described by Weller and Cook (Weller and Cook, 1986).

\section{Application of Bacillus species as Biocontrol against Fusarium oxysporum}

Serial dilutions from pure cultures of the isolated bacteria were loaded into wells opened at the periphery of nutrient agar at equal distance from the center as shown in the Figure (4.13).

Pathogenic Fusarium spp isolates from diseased plants were inoculated at the center of the plates $0,1,2$, and 3 days after the loading of bacteria. Plates were incubated for several days at ambient temperature. Diameters of inhibition zones of fungal growth were measured. Commercial antifungal chemical (carbendazim) was used as a control and its activity was compared with the bacterial inhibition zones of fungal growth. The concentrations of carbendazim used were $0.4,0.8,1.0,2.0 \mathrm{~g} / \mathrm{L}$

\section{Pot Experiment}

Ten-centimeter plastic pots with perforated 
bases were washed in detergent, soaked in Biocide overnight, and then rinsed and stacked back on the shelves in the preparation room. Soil was put into autoclavable bags and sterilized in the autoclave at $121 \mathrm{C}, 15 \mathrm{~min}$. Each pot was filled with $500 \mathrm{~g}$ soil. The soil was taken from the same field on which the pathogenic F. oxysporum was isolated (Fisher, 1982).

The bacterial suspension was adjusted turbidimetrically (McFarland standard) to about 108 colony-forming units (CFU/mL) for each experiment. The bacterial suspensions were used for seed coating (Mostapha, 2004) as described below. Seeds were immersed in a slurry solution $(10 \%$ sucrose) to allow bacteria to adhere on the seeds.

Seeds of three plant species: watermelon, muskmelon, and cucumber, were planted in the mentioned pots and were irrigated with $50 \mathrm{ml}$ daily, these pots were distributed into four groups:

Positive control group, negative control group, chemically treated group, and biologically treated group. Conidial suspensions $\left(10^{6}\right.$ conidia/ $\left.\mathrm{ml}\right)$ were prepared by washing the 7 to 14 day old PDA slants with sterile distilled water and filtering the suspension through cheesecloth. Conidial densities in the suspension were determined by use of a hemcytometer under a compound microscope (Hammar et al., 1989). Conidial suspensions were inserted in all the groups except the negative control group. The experimental groups, positive control group, biological treated group, and the carbendazim treated group were injected by macroconidia of $F$. oxysporum ( $1 \mathrm{ml}$ of suspension which had $10^{6}$ macroconidia). The injections were done by a syringe nearly $5 \mathrm{~cm}$ subsurface of soil around the plantlets root system.
By planting rooted cuttings in soil for two weeks, wounding roots by passing a metal spatula through the soil around each plant, and then pouring water-containing conidia of the pathogen onto the soil (Fisher, 1998). In the chemically treated group carbendazim was sprayed (Omar, 2006).

\section{Results and Discussion}

\section{Microscopic identification of $F$. oxysporum}

All isolates of $F$. oxysporum produced abundant, single-celled, oval or oblong microconidia. Short and unbranched microconidiophores and long, four to five septate, slightly falcate macroconidia. These were the most important morphological characteristics to identify $F$. oxysporum. Chlamydoconidia are round hyaline, smooth walled, borne singly or in pairs on short lateral branches as shown in Figure 1.

\section{Characteristics of $F$. oxysporum}

On PDA: Colony morphology on PDA varies widely. Mycelia may be floccose, spare or abundant and range in color from white to pale violet. $F$. oxysporum usually produces a pale to dark violet or dark magenta pigment in the agar. Colony morphology, pigmentation and growth rates of cultures of most Fusarium species on PDA are reasonably consistent if the medium is prepared in a consistent manner, and if the cultures are initiated from standard inocula and incubated under standard conditions. These colony characteristics often are useful secondary criteria for identification.

The isolates had different colony characteristics and pigmentation on PDA. The aerial mycelium of $F$. oxysporum isolates ranged from white to purple and the 
undersurface of colonies ranged from white to dark purple. The aerial mycelium and the undersurface of colonies for $F$. solani isolates ranged from cream to tan.

Conidia formed on PDA are usually variable in shape and size and so are less reliable for use in identification.

On Komada's Medium: The colonies of $F$. oxysporum on Komada's Medium are pigmented with a reddish purple color and surmounted by a pinkish white aerial mycelium as shown in Figure 2. Other Fusarium species are suppressed.

On SDA Medium: $F$. oxysporum grows rapidly on Sabouraud dextrose agar at $25^{\circ} \mathrm{C}$ and roduces woolly to cottony, flat, spreading colonies.

\section{Identification of Bacillus subtilis}

Bacillus colonies are typically white and dry or pasty looking but some form very mucoid colonies (that can drip onto the lid of the plate). Bacillus cells are typically fairly rectangular rods. Often occurring in pairs or chains.

\section{Characteristics of Bacillus}

The following table (1) illustrates the examined microscopically and biochemical characteristics of Bacillus isolates. The results of the tested parameters were according to PIB win software.

\section{In vitro Inhibition of $F$. oxysporum by Soil Bacterial Isolates}

The size of the zone of inhibition of fungal growth around each bacterial species was used as a measure of the ability of those bacteria to inhibit $F$. oxysporum. Zones of growth inhibition were detected around bacterial strains placed at three positions on the plate Table 2 . The damage caused by the bacterium to the fungal mycelium was studied microscopically. The mycelium along with the agar disc present in the inhibition zone and control mycelium were taken, stained with lactophenol cotton blue and observed under microscope. Light microscope study revealed the presence of abnormal hyphae, with condensation and deformation as shown in Figure 3. There were swellings of mycelial tips and cells in between.

The damage caused by the bacterium to the fungal mycelium was studied microscopically. The mycelium along with the agar disc present in the inhibition zone and control mycelium were taken, stained with lactophenol cotton blue and observed under microscope. Light microscope study revealed the presence of abnormal hyphae, with condensation and deformation as shown in Figure 3.B. There were swellings of mycelial tips and cells in between.

Application of Bacillus subtilis on Different Days old F. oxysporum Culture

Table 2 Shows that the inhibitory effect of various dilutions of one $B$. subtilis isolate on different days old $F$.oxysporum culture.

\section{Pot Trials}

The results of a pot trial are shown in tables 3-5. Here we have four groups, one of which had no pathogen added (the negative control), one to which the pathogen was added (the positive control), one with the pathogen and positive biocontrol Bacillus antagonists from the plate competition studies above (biologically treated), and the last one had both the pathogen and the antifungal agent carbendazim (chemically treated). 
Effect of Different Treatments on Dry Weight, Stem Length and Dry Weight of Watermelon, Cucumber and Muskmelon

In watermelon, cucumber and muskmelon tables 3-5, the results showed that the negative control group is growing well indicating that the growth conditions are normal. The pathogen infected (positive control) group showed poor growth (as expected). The biologically treatment was efficient in reducing disease and allowed the plants to grow pretty well. The chemically treated group showed that the carbendazim ability to reduce disease is little more efficient than the biological treatment in Watermelon but has similar efficiencies in cucumber and Muskmelon.

Fusarium wilt disease is caused by pathogenic forms of the soil-inhabiting fungus $F$. oxysporum. $F$. oxysporum is a major disease problem on many crops. Currently, control of this pathogen is generally by chemical control (fungicides). Synthetic fungicides are considered the primary means to control Fusarium disease. However, several reasons, such as the public's growing concern for the human health conditions and the environmental pollution associated with fungicides usage and development of fungicide- resistant strains of Fusarium.

Biological control has emerged as one of the most promising alternatives to chemicals. During the last twenty years, several biological control agents have been widely investigated for use on different pathogens.

In this study we investigated the effect of various Bacillus species isolated from soil on Fusarium oxysporum both on plates and on plants grown in pots. The efficacy of the Bacillus was also compared to the chemical antifungal agent carbendazim.

\section{Characteristics of Fusarium oxysporum}

$F$. oxysporum usually produces a pale to dark violet or dark magenta pigment on the agar if incubated in dark place. PDA is used by some researchers for the isolation of Fusarium species. We do not recommend this medium for this purpose, as many saprophytic fungi and bacteria also can grow on the medium and interfere with the recovery of the Fusarium present. If PDA is used for the recovery of fungi from plant material, then the concentration of potato and dextrose should be reduced by 50-75\%, and broad -spectrum antibiotics should be included in the medium to inhibit bacterial growth (Rothrock and Gottlies, 1981).

Colonies of $F$. oxysporum are distinctly pigmented on Komada's medium, and usually separable from other Fusarium species on this basis. Growth of other Fusarium species may be suppressed by the medium, and this medium often is not a good choice for the recovery of Fusarium communities that contain species other than F. oxysporum (Booth, 1971). In our study we used three different media (PDA, Komadas media, and SDA) for the isolation of Fusarium oxysporum. This combination should be sufficient for the isolation of Fusarium oxysporum. The hyphae of $F$. oxysporum are septate and hyaline. Conidiophores of this organism are short monophialids. Macroconidia are abundant, slightly sickleshaped, thin- walled and delicate, with an attenuated apical cell and a footshaped basal cell, 3-5 septate. Microconidia abundant, in false heads only. Mostly nonseptate, ellipsoidal to cylindrical, straightly curved. Chlamydospores formed singly or in pairs and may be profuse in some strains (Booth, 1971). Microscopic examination was also employed in this study for confirming identify of Fusarium oxysporum. 
In vitro Inhibition of Fusarium oxysporum by Soil Bacterial Isolates

Bacillus subtilis was isolated from soil samples. The bacterium was identified according to standard methods including biochemical tests and microscopic examination. In the dual culture experiments, all bacterial isolates tested inhibited the growth of $F$. oxysporum. Zones of inhibition were observed between the colonies of pathogen and bacteria. The inhibition zone could be due to the effect of diffusible inhibitory substances produced by the bacteria, which suppressed the growth of $F$. oxysporum. The presence and size of the zones of inhibition have been used as an evidence of the production of antifungal compounds by the bacteria (Rothrock and Gottlies, 1981).

In this study we showed that the increase in bacterial concentration increases the inhibition zones, and the application of Bacillus subtilis and $F$. oxysporum together showed larger inhibition zones. An interaction zone appeared between the Bacillus and Fusarium on plate, the hyphae from these fungi stained with cotton blue, were free of cytoplasmic content, possibly by the effects of the inhibitory substance(s) produced by the Bacillus assayed as the biocontrol agent (Ruiz-Duenas, 1996). Further studies are needed in order to define the nature of the inhibitory substance.

Table.1 Examined Biochemical and Microscopic Characteristics Bacillus Isolates

\begin{tabular}{ll}
\hline Test & Result \\
\hline Gram stain & Gram positive \\
Spores shape & Oval \\
Spores position & Central \\
Spores bulging & negative \\
Casein hydrolysis & positive \\
Hippurate hydrolysis & positive \\
Starch hydrolysis & positive \\
Urease & positive \\
Chloramphenicol resistance & $\mathrm{S}$ \\
Nalidixic acid & $\mathrm{S}$ \\
Polymyxin B & $\mathrm{R}$ \\
Streptomycin & $\mathrm{S}$ \\
Fructose acid & positive \\
Galactose acid & negative \\
Lactose acid & negative \\
Xylose acid & Positive \\
Citrate utilization & positive \\
Growth at 50 0C & positive \\
Growth in 10\% NaCl & positive \\
Anaerobic growth & negative \\
Nitrate reduction & positive \\
Oxidase reaction & positive \\
Voges-Proskauer test & positive \\
\hline
\end{tabular}


Table.2 Illustrates the Average Diameter of Inhibition Zones Produced by Serial Dilutions of B. subtilis on Three Days Old F. oxysporum Culture

\begin{tabular}{|c|c|c|c|}
\hline \multirow[t]{2}{*}{ Bacterial dilution } & \multicolumn{3}{|c|}{ Diameter of inhibition zone $(\mathrm{mm})$} \\
\hline & Day 1 & Day 2 & Day 3 \\
\hline $\begin{array}{l}\text { Stock culture } \\
(2.6 \times 107) \mathrm{CFU} / \mathrm{ml}\end{array}$ & 6 & 6 & 6 \\
\hline $10-1$ & 3 & 6 & 0 \\
\hline $10-2$ & 0 & 4 & 0 \\
\hline $10-3$ & 0 & 0 & 0 \\
\hline $10-4$ & 0 & 0 & 0 \\
\hline $10-5$ & 0 & 0 & 0 \\
\hline
\end{tabular}

Table.3 Effect of Biological and Chemical Control on Stem Length, Dry Weight, Root Length of Watermelon

\begin{tabular}{llll}
\hline Group & Stem length & Dry weight & Root length \\
\hline $\begin{array}{l}\text { Chemically treated } \\
(\mathrm{n}=16)\end{array}$ & $35.3 \pm 3.0(\mathrm{P}=0.01)$ & $2.4 \pm 0.2(\mathrm{P}=0.01)$ & $10.1 \pm 1.0(\mathrm{P}=0.31)$ \\
$\begin{array}{l}\text { Biologically treated } \\
(\mathrm{n}=16)\end{array}$ & $25.0 \pm 5.0(\mathrm{P}=0.01)$ & $\begin{array}{l}2.6 \pm 0.2 \\
(\mathrm{P}=0.01)\end{array}$ \\
$\begin{array}{l}\text { Positive control }(\mathrm{n}=16) \\
\text { Negative control }(\mathrm{n}=16)\end{array}$ & $14.8 \pm 4.0$ & $1.2 \pm 0.2$ & $11.3 \pm 1.5(\mathrm{P}=0.03)$ \\
\hline
\end{tabular}

Table.4 Effect of Biological and Chemical Control on Stem Length, Dry Weight, Root Length of Cucumber

\begin{tabular}{llll}
\hline Group & Stem length & Dry weight & Root length \\
\hline Chemically treated & $24.6 \pm 8.0$ & $3.0 \pm 0.5$ & $16 \pm 2.0$ \\
$(\mathrm{n}=16)$ & $(\mathrm{P}=0.01)$ & $(\mathrm{P}=0.01)$ & $(\mathrm{P}=0.59)$ \\
Biologically treated & $24.5 \pm 6.0$ & $2.6 \pm 0.5$ & $17.5 \pm 3.0$ \\
$(\mathrm{n}=16)$ & $(\mathrm{P}=0.01)$ & $(\mathrm{P}=0.01)$ & $(\mathrm{P}=0.02)$ \\
Positive control $(\mathrm{n}=16)$ & $11.0 \pm 4.0$ & $1.2 \pm 0.2$ & $15.0 \pm 3.0$ \\
Negative control $(\mathrm{n}=16)$ & $23.0 \pm 5.2$ & $2.7 \pm 0.4$ & $17.5 \pm 2.0$ \\
\hline
\end{tabular}

Table.5 Effect of Biological and Chemical Control on Stem Length, Dry Weight, Root Length of Muskmelon

\begin{tabular}{llll}
\hline Group & Stem length & Dry weight & Root length \\
\hline $\begin{array}{l}\text { Chemically treated } \\
(\mathrm{n}=16)\end{array}$ & $27.6 \pm 3.0(\mathrm{P}=0.01)$ & $5.8 \pm 0.6(\mathrm{P}=0.01)$ & $14.0 \pm 2.0(\mathrm{P}=0.02)$ \\
$\begin{array}{l}\text { Biologically treated } \\
(\mathrm{n}=16)\end{array}$ & $26 \pm 4.5(\mathrm{P}=0.01)$ & $2.9 \pm 0.4(\mathrm{P}=0.04)$ & $16.1 \pm 3.6(\mathrm{P}=0.01)$ \\
Positive control $(\mathrm{n}=16)$ & $18.4 \pm 4.8$ & $2.4 \pm 0.6$ & $11.6 \pm 2.4$ \\
Negative control $(\mathrm{n}=16)$ & $27.2 \pm 3.2$ & $3.0 \pm 0.6$ & $15.2 \pm 2.4$ \\
\hline
\end{tabular}


Application of Carbendazim as Chemical and Biocontrol Control agent against Fusarium oxysporum

Carbendazim reduced disease symptoms by over $50 \%$ when used at $>50 \mu \mathrm{g} \mathrm{ml-1}$, but had little effect at lower concentrations (Omar T.M., 2006). While results from bioassays in dual cultures suggest that production of antifungal substance(s) by these bacteria may be involved in the inhibition of hyphal growth of Fusarium. This is supported by the following observations: (a) for all bacterial isolates selected initially, there was no direct contact between fungal mycelium and bacterial colonies, so that the inhibition of fungal growth was due to substances that diffused into the agar medium, (b) the PDA medium used for dual cultures is rich in nutrients and thus competition for them might be excluded, and (c) antibiosis is the general mode of antagonism observed for Bacillus spp. Most Bacillus spp produce antibiotics, many of which have antifungal activity (Edwrds et al., 1994).

\section{Symptoms Observed on Infected Plants}

Infection of the host occurs by penetration of the roots, primarily in the area of elongation, and is aided by wounds. Disease severity is maximum at soil temperature of $24{ }^{\circ} \mathrm{C}$ and declines dramatically above $30^{\circ} \mathrm{C}$. Low soil moisture favors the pathogen and accentuates the wilting symptoms. Moreover, High nitrogen and acidic soils favor disease development.

When applied to seeds $B$. subtilis provided crop protection mostly due to direct control of soil borne pathogens through efficient production of various fungitoxic metabolites (Backman et al., 1997). Several mechanisms have been suggested for the ability of $B$. subtilis to inhibit fungal pathogen. Bacillus subtilis inhibits plant pathogen spore germination, disrupts germ tube growth and interferes with attachment of the pathogen to the plant. Colonies of Bacillus subtilis take up space on the roots, leaving less space for occupation by disease pathogens. Bacillus subtilis consumes exudates, which deprives disease pathogen of a major food source, thereby inhibiting their ability to thrive and reproduce. Bacillus subtilis has been shown to combat pathogenic fungi through the production of iturin, which inhibits the pathogens growth (Backman et al., 1997).

When applied directly to seeds, the bacteria colonize the developing root system, competing with disease organisms that attack root system (Backman et al., 1997). Iturin is a class of lipopeptide antibiotics. Iturins help Bacillus subtilis bacteria out compete other microorganisms by either killing them or reducing their growth rate. Iturins can also have direct fungicidal activity of pathogens.

Lazzaretti et al., (Lazzaretti et al., 1994 ) reported that $B$. subtilis inhibited the growth of various fungi including $F$.oxysporum in vitro. This may be due to production of an agent containing the antifungal antibiotics bacillomycins. The pathogen may cause disease by avoiding or overcoming any of these defense mechanisms or by vascular occlusion. The cause of wilting by the pathogen may be due to either vascular occlusion resulting in the failure of water transport or toxin production. With $F$. oxysporum f. sp. Melonis however, wilt resistant muskmelon plants also harbor the pathogen extensively within the vascular elements (Cohen et al., 1986).

This phenomenon may be due to degradation of fungal cell wall-degrading enzymes (CWDEs) by the resistant host as a defense response or alternatively, the fungus 
may not be expressing these factors in resistant plants, but the mechanisms governing this resistance are unknown. Likewise, the resistance mechanisms in watermelon have not been elucidated (Biles et al., 1990).

\section{Effect of Different Treatments in Pot Trials}

The observed biological effects of applying the biological agent (B. subtilis) are also due to changes in the physiology of the plant. In the first place, the tolerance towards a biotic and biotic stress factors is improved because the root system of the plant is strengthened, and hence also the uptake of water and nutrients. In addition, many results indicate that the application of Bacillus subtilis changes the phytohormone balance in the plant in such a manner that greater quantities of reserve substances are incorporated into storage organs. Hence the plant root length, stem length and dry weight are expected to be improved by application of biocontrol agents.

The results of this study have shown that the dry weight and stem length of watermelon, cucumber and muskmelon were significantly different in chemically and biologically treated groups as compared to the positive control group.

Also we have observed that the root length was significantly different in only biologically treated group in watermelon, cucumber and muskmelon but not in the chemically treated group again in comparison to the positive control.

In conclusion, we have been able to isolate bacterial isolate of Bacillus subtilis, which have shown to have on observable antifungal activity against Fusarium oxysporum. Therefore we suggest that
Bacillus subtilis can be used in the control of Fusarium oxysporum in agriculture, in particular watermelon, cucumber and muskmelon. In addition we suggest further studies, on the different types of antifungal that are produced by these bacteria.

\section{References}

Backman, P. A., Wilson, M., and Murphy, J.F. 1997. Bacteria for biological control of plant diseases. Pages 95109 in: Environmentally Safe Approaches to Crop Disease Control. N. A. Rechcigl and J. E. Rechcigl, eds. Lewis Publishers, Boca Raton, FL.

Biles, C.L., and Martyn, R.D. 1989. Local and systemic resistance induced in watermelons by formae speciales of Fusarium oxysporum. Phytopathol., 79: 856-860.

Biles, C.L., Martyn, R.D., and Netzer, D. 1990. In vitro inhibitory activity of xylem exudates from cucurbits towards Fusarium oxysporum microconidia. Phytoparasitica, 18: 41-49.

Booth, C. 1971. The Genus Fusarium. C.M.I. Kew, Surrey, England. 273 pp.

Bowyer, P. 1999. Plant disease caused by fungi: phytopathogenicity In: Molecular Fungal Biology, (RP Oliver, M Schweizer), Cambridge University Press, Cambridge.

Burgess, L.W., Liddell, C.M., and Summerell, B.A. 1988. Laboratory manual for Fusarium research, 2nd ed. University of Sydney, Sydney. Phytopathol., 81: 462-469.

Cohen, R., Riov, J., Lisker, N., and Katan, J. 1986. Involvement of ethylene in herbicide-induced resistance to Fusarium oxysporum f. sp. melonis. Phytopathol., 76: 1281-1285. 
Edwrds, S.G., Mckay, T., and Seddon, B. 1994. Interaction of Bacillus spp phytopathogenic fungi. Methods of analysis and manipulation for biocontrol purposes. Ecol. plant pathogens, Pp.101-118.

Farias, G.M. 1987. Quantitative investigations of Fusarium oxysporum and F. solani colonization and rot of Glycine max cv. Essex seedlings. M.S. Thesis. VPI\&SU, Blacksburg, VA, 102 pp.

Fisher, D.T. 1982. Effects of some imidazole and triazole fungicides on white clover and symbiotic nitrogen fixation by rhizobium trifoli. Ann. Biol., 101-19.

Fisher, N.L., Marasas, W.F.O., and Toussoun, T.A.N. 1998. Taxonomic importance of micriconidial chains in Fusarium section liseola and effects of water potential on their formation. Mycologia, 75: 693-698.

Gamliel, A. and Yarden, O. 1998. Diversification of Diseases Affecting Herb Crops in Israel Accompanies the Increase in Herb Crop Production Phytoparasitica, 26: 1-6

Guetsky, R., Shtienberg, D., Elad, Y., Fischer, E., and Dinoor, A. 2002. Improving biological control by combining biocontrol agents each with several mechanisms of disease suppression. Phytopathol., 92: 976985.

Hammar, S., Fulbright, D.W., and Adams, G.C. 1989. Association of doublestranded RNA with low virulence in an isolate of Leucostoma persoonii. Phytopathol., 79: 568-572.

Komada, A. 1975. Development of a selective medium for quantitative isolation of Fusarium oxysporum from natural soil. Rev. Plant. Prot. Res., (Tokyo) 8: 114-125.
Larkin, R.P., and Fravel, D.R. 1998. Efficacy of various fungal and bacterial biocontrol organisms for control of Fusarium wilt of tomato. Plant dis., 82: 1022-1028.

Lazzaretti, E., Menten, J.O. and Bettiol, W. 1994. Bacillus subtilis antagonistic to the principal pathogens associated with bean and wheat seeds. Phytopathol. Venezolana, 7: 42-46.

Mostapha, N.K. 2004. Biological Control of Rhizoctonia solani, the Causal Agent of Rice Sheath Blight by Antagonistics Bacteria in Greenhouse and Field Conditions. Plant Pathol., 2: $88-9$.

Omar, T.M. 2006. Biological control of Fusarium crown and root rot of tomato with antagonistic bacteria and integrated control when combined with the fungicide carbendazim. Plant pathol., 55: 92-99.

Powell, K. 1993. Biological control the answer for sustainable agriculture. Mycologist, 7: 75-78.

Rothrock, C. and Gottlies, D. 1981. importance of antibiotic production in antagonism of selected streptomyces species to two soil-borne plant pathogen. J. Antibiot., 34: 830-835.

Ruiz-Duenas, F.J. 1996. Enzymatic activates of Trametes versicdor and Pleurotus eryngii implicated in biocontrol of Fusarium oxysporum f.sp, lycopersici. Curr. Microbiol., 32: 151-155.

Saravanan, T. and Valluvaparidasan, V. 2001. Fungitoxic Effect of Biocontrol Agents and Plant Extracts on Seed Borne Fungi of Sorghum. Pak. J. Biol. Sci., 6: 676-678.

Schickler, H., Chet, I. 1997. Heterologous chitinase gene expression to improve plant defence against phytopathogenic fungi. $J$. Ind. Mirobiol. Biotechnol., 19: 196-201. 
Swift, C.E., Wickiffe, E.R., and Schwartz, H.F. 2002. Vegetative compatibility groups of Fusarium oxysporum f.sp cepae from onion in Colorado. Plant Dis., 86: 606.610.

United States Environmental Protection Agency. Topics: Biopesticides. Online. Office of Pesticide Programs.

Viterbo, A., Ramot, O., Chernin, L., Chet, I. 2002. Significance of lytic enzymes from Trichoderma spp. in the biocontrol of fungal plant pathogens.

Anton. Leeuw., 81: 549-556.
Weller, D.M. and Cook, R. 1986. Increased growth of wheat by seed treatment with Fluorescent pseudomonads and implications of Pythium control. Plant Pathol., 8: 328-344.

Wong, P.T.W. and Baker, R. 1984. Suppression of wheat take-all and Ophiobolos patch by Fluorescent pseudomonads from Fusarium suppressive soil. Soil Biol. Biochem., 16: 397-403.

\section{How to cite this article:}

Abboud Y. Elkichaoui. 2016. Safe Approach to the Biological Control of the Fusarium oxysporum by Soil Isolates of Bacillus species from Gaza Strip. Int.J.Curr.Microbiol.App.Sci. 5(9): 788-800. doi: http://dx.doi.org/10.20546/ijcmas.2016.509.090 